\title{
Advances in cellular evaluation and standard of antioxidant activity
}

\author{
Qi Wu${ }^{1}$, Ruirui Song ${ }^{1}$, Lin Zhao $^{1}$ and Zhenyu Yun ${ }^{1, a}$ \\ ${ }^{1}$ China National Institute of Standardization, Institute of Food and Agriculture Standardization, No.4 Zhi Chun Road, Haidian District, \\ Beijing, China
}

\begin{abstract}
Reactive oxygen species (ROS) function significantly in cell signal transduction and homeostasis. High ROS concentration can cause oxidative damage to cells and lead to various diseases consequently. Significantly, antioxidants can scavenge free radicals and reduce the risk of cardiovascular diseases, heart diseases and cancer. In the present study, a review was carried out concerning current methods for evaluating antioxidant activity, focusing on cellular determining antioxidant activity, in combination with the investigation of evaluation models of antioxidant activity established by different cell lines, which may provide a reference for further evaluation of antioxidant activity by establishing cell models.
\end{abstract}

\section{Introduction}

Reactive oxygen species (ROS), such as superoxide anions, hydrogen peroxide, hydroxyl radicals and singlet oxygen, are highly active molecules that are derived predominantly from oxygen consumed during metabolism. ROS is an essential component of human cells and involves critically in physiological processes of cell signal transduction and homeostasis[1]. Normally, ROS is produced by respiratory chain of mitochondria and peroxidase system as well as from exogenous sources. Among them, peroxidase system includes NADPH oxidase (NOX), xanthine oxidase, nitric oxide synthase (NOS), arachidonic acid, cytochrome P450 enzyme, lipoxygenase, cyclooxygenase and other metabolic enzymes[2]. The level of ROS is crucial to cell homeostasis that can induce different biochemical reactions at different levels. At low concentrations, ROS participates in cell proliferation, differentiation and apoptosis, and activates signaling molecules of stress response survival pathway. Meanwhile, excessive concentration of ROS can cause oxidative damage to cell membranes, fats, proteins and DNA, leading to aging of organisms, as well as cardiovascular diseases, diabetes, cancer, atherosclerosis, rheumatoid arthritis, neurodegenerative diseases and other diseases[3-4].

Antioxidants are a class of biologically active compounds that can effectively scavenge intracellular free radicals, suppress lipid peroxidation and alleviate other oxidative damage to cells. Generous studies have documented that antioxidants also have anti-cancer, antiinflammatory and anti-aging functions, highlighting that the supplementation of antioxidants is of great significance to human health. Antioxidants are widely found in vegetables, fruits, green algae, tea, traditional
Chinese medicines, etc., which are primarily supplemented through dietary intake. With the improvement of economy and development of food industry in our country, self-health awareness of consumers is enhanced ceaselessly. People's demand for food develops from eating-full and eating-well in the past to eating-healthy at present. Significantly, antioxidant agents can scavenge free radicals, protect cell macro-molecules from damage induced by oxidative stress, and reduce the risk of cardiovascular diseases, heart diseases and cancer. In this regard, products that claim to have antioxidant activity are emerging in the market, but not all antioxidants have the same efficacy. Therefore, antioxidant activity evaluation of antioxidants has become a concern for the academia and public.

\section{Evaluation methods of antioxidant activity}

\subsection{In vitro evaluation methods}

In vitro antioxidant activity evaluation is composed of chemical and cellular methods.

\subsubsection{Chemical methods.}

In vitro chemical assay evaluates antioxidant activity by using two purified chemical reaction systems, namely, electron transfer (ET) and hydrogen atom transfer (HAT). To be specific, ET is mainly characterized by oxidant color changes during reaction, while the antioxidant competes with substrate (probe) for free radicals in HAT. Furthermore, ET covers Trolox equivalent antioxidant capacity (TEAC) assay, ferric ion reducing antioxidant 
power (FRAP) assay, copper reducing capacity assay, ABTS radical scavenging capacity assay and 2,2diphenyl-1-picryhydrazyl (DPPH) radical scavenging capacity assay. While HAT includes saffron decolorization assay, oxygen radical absorbance capacity (ORAC) assay and total radical-trapping antioxidant parameter (TRAP) assay[5]. At present, common approaches applied during chemical evaluation include DPPH radical scavenging capacity assay, FRAP assay, ABTS radical scavenging capacity assay, TRAP assay and inhibition of lipid peroxide. $\mathrm{H} 2 \mathrm{O} 2$ and DPPH are the most frequently used free radical initiators. Besides, Rphycoerythrin fluorescent substance and 2',7'dichlorohydrofluorescein diacetate (DCFH-DA) are generally applied as target probes. Shi et al.[6] carried out an experiment by extracting polysaccharides (PE) from Enteromorpha prolifera, associated with the preparation of degradable polysaccharides (DPE) and carboxymethyl derivatives (CDPE). The antioxidant activity of CDPE in vitro was tested and analyzed by DPPH free radical scavenging capacity assay, hydroxyl $\left(\mathrm{HO}^{-}\right)$radical scavenging capacity assay, superoxide $\left(\mathrm{O}^{-}\right)$ radical scavenging capacity assay and iron reducing capacity assay. Corresponding results showed that the antioxidant activity of these three substances increased with the increase of concentration in the range of 1-5 $\mathrm{mg} / \mathrm{ml}$, and CDPE had higher antioxidant activity. Furthermore, Biondo et al.[7] analyzed antioxidant capacity of spices, herbal and citrus essential oils by DPPH, ABTS, FRAP and ORAC assays, with clove and cinnamon essential oils found to exhibit higher antioxidant activity. Besides, according to the results of GC-MS to identify active ingredients in essential oils, eugenol and caryophyllene were mainly contained in clove and cinnamon essential oils. Moreover, principal component analysis (PCA) showed that essential oil extracted from spices had good antioxidant activity. In vitro chemical assay dose, however, have some drawbacks despite its role in reflecting antioxidant activity to some extent. For example, it can not reflect physiological conditions of cells due to the failure to take intracellular bioavailability, absorption and metabolism of antioxidants into consideration. In addition, there is inconsistency in the types of free radicals used in the reaction system compared to those of physiological free radicals, and it is also the same concerning the types of molecules used to detect free radical damage relative to those used in vivo, resulting in no significant in vivo effect of antioxidants detected in vitro.

\subsubsection{Cellular methods}

Cellular antioxidant modeling in vitro is such a method treating cells with stress sources to produce free radicals and destroy the balance of intracellular oxidation and reduction. In this method, intracellular redox status is repaired by scavenging free radicals with the addition of antioxidant substances. Consequently, with the application of this method, changes of physiological conditions can be simulated by the changes of cell morphology, cell survival rate, ROS level, antioxidant enzymes and lipid peroxides. In 2007, Wolfe et al.[8] evaluated the antioxidant activity of various antioxidants and foods by establishing an oxidative stress model of hepatocytes (HepG2 cells) induced by 2,2'-azobis (2amidinopropane) dihydrochloride (AAPH). In the experiment, cells were pretreated with a mixture of test substance and self-nonfluorescent agent DCFH-DA. Intracellular esterase decomposed DCFH-DA to form reduced dichlorofluorescein (DCFH) with stronger polarity, and the latter substance was easily oxidized to fluorescent DCF by oxygen free radicals or ROS, while antioxidants were observed to have the ability to block the oxidation mentioned above. Besides, the study revealed that the reduction of DCF can reflect the activity of antioxidants when compared with the control group. Furthermore, following the establishment of cellular antioxidant activity (CAA) assay, several research groups have established evaluation approaches of antioxidant activity in other cell models on the basis of CAA assay, which enriches and develops cell antioxidant assays. At present, the proposed method is frequently used in screening new antioxidants and evaluating the effect of antioxidants.

\subsection{In vivo evaluation methods}

In vivo evaluation includes animal models and clinical studies, which is generally used to study the pathogenesis of certain diseases and can objectively reflect actual biological activity of antioxidants.

\subsubsection{Animal models}

As evidenced by many oxidative stress models, tea and polyphenols can prevent or attenuate the decrease of antioxidant enzyme activity. Supplementation of green tea polyphenols to drinking water can significantly inhibit the decrease of catalase and glutathione reductase activity in epidermis of hairless mice induced by UVB[9]. In addition, oral test in mice infected with Mycobacterium tuberculosis showed that green tea extract could also prevent the decrease of superoxide dismutase activity[10]. When mice were exposed to carcinogens, both dark tea and green tea extracts could increase Superoxide dismutase (SOD) activity[11]. Furthermore, chemotherapy-induced peripheral neuropathy is the most common side effect during antitumor therapy, with unclear mechanism and no effective therapeutic approaches at present. Many drugs such as antidepressants, anticonvulsants and antispasmodics exert no obvious effect in clinical application. However and importantly, antioxidant agents have protective effects on free radical damage. The therapeutic effect of antioxidants on peripheral neuropathy has been detected by many studies with established animal models[9]. Additionally, research team led by Gong[12] and Vashistha[13] studied the effect of matrine and ferulic acid on vincristine-induced neuropathic pain in animal models, respectively. Behavioral, electrophysiological, biochemical and histopathological analysis supported 
that both ferulic acid and matrine could alleviate peripheral neuropathy induced by vincristine.

\subsubsection{Clinical studies}

Clinical study takes patients or healthy people as the research objects. It is the final detection for the biological function of antioxidants and used in the development of new drugs and treatment methods generally. Antioxidants have anti-cancer, antiinflammatory and anti-aging functions. Therefore, the clinical research before the application of antioxidants in human body is significant. Traumatic brain injury (TBI) had been widely regarded as a complex pathological process. The mortality or disability rate of TBI patients is more than $20 \%[14]$. Studies have proved that oxidative stress plays a key role in TBI[15]. A follow-up study of 44 patients with brain trauma by RodrguezRodrguez et al. [16]showed that 26 patients achieved good functional outcome (GFO) (good recovery or moderate disability) and 17 patients had poor functional outcome (PFO) (severe disability, vegetative or death) in six months after brain trauma. Biomarker analysis showed that serum total antioxidant capacity in patients with PFO were higher than those in patients with GFO. These results provide information about the body's antioxidant capacity and support strategies for optimizing antioxidant therapy in patients with traumatic brain injury. In order to study the efficacy of Mastiha in the treatment process of atherosclerosis and cardiovascular disease, a clinical trial of biochemical marker method was designed. Studies have shown that taking 2 to 10 grams of Mastiha daily can reduce blood lipid and blood sugar, and has a protective effect on the heart. Although antioxidant drugs can be used to treat many diseases, there is a lack of clinical data to support their application in the population[17,18].

In vivo evaluation method is indeed a better approach to evaluate the actual effect of antioxidants in vivo. Nevertheless, it is expensive, time-consuming, cumbersome and restricted by various influencing factors including randomness of allocation, double blindness, integrity of follow-up, interference and pollution, which is not suitable for rapid evaluation and preliminary screening of samples in bulk.

\section{Advances in cellular evaluation of antioxidant activity}

Evaluation of antioxidant activity in vitro can contribute to observing the absorption and distribution of antioxidants in biological environment on the basis of cell model establishment. It can better illustrate the effect of antioxidants in physiological conditions, cells or in vivo, and reflect their antioxidant activity more comprehensively. Simultaneously, in vitro cell assay can also specifically evaluate the antioxidant activity of test substances according to special cells from different human tissues and different oxidative stress modes, exhibiting great advantages in cost and convenience of operation than animal models and clinical studies.
In this paper, recent studies on cell antioxidant models were summarized, in combination with the summary of related cell lines, cell passages, oxidant/antioxidant substances and test indicators used in the model. The specific contents are shown in Table 1. According to the table, various cell lines are used at present, such as hepatocyte (HepG2), human colon carcinoma cell line (Caco-2), erythrocyte (RBC), endothelial cell (human umbilical vein endothelial cell), mouse mononuclear macrophage leukemia cell (RAW264.7), human embryonic kidney cell (HEK-293), etc. Cells are generally within 55 generations. Common oxidants are $\mathrm{H}_{2} \mathrm{O}_{2}, 2$,2'-azo (2-amidinepropane), 2,2'azobis(2-amidinopropane) dihydrochloride (ABAP), AAPH and tert-butyl hydroperoxide (t-BHP), which can induce the formation of peroxide radicals. Most antioxidants are natural extracts. Quercetin and Lascorbic acid are commonly the controls of antioxidants. There are five evaluation indicators for cell antioxidant model generally, such as the degree of cell damage, cell survival rate, intracellular ROS level, lipid peroxides level and antioxidant enzymes level and activity. MTT and MTS methods are used to detect cell damage and degree. MTT method shares the same principle of operation with MTS method, that is, various dehydrogenases in mitochondria of living cells reduce MTT or MTS to formazan, which is insoluble in water and deposited in cells to make cells blue. The depth of the color is proportional to the number of living cells in a certain range. Intracellular ROS levels are generally determined by fluorescence probe DCFH-DA. DCFHDA has no fluorescence, which is hydrolyzed by lactonease to form DCFH after entering cells. DCFH can not pass through cell membrane and remain in cells, and then oxidized by ROS into fluorescent DCF that can directly reflect the level of intracellular ROS according to the intensity of fluorescence. Furthermore, lipid peroxides are often detected by thiobarbituric acidreactive substances (TBARs) with malondialdehyde (MDA) as the evaluation index. SOD, catalase (CAT) and glutathione peroxidase (GSH-Px) are key components of intracellular antioxidant system, possessing great impact on intracellular redox status. The expression level of these enzymes and their enzymatic activity can indirectly reflect the oxidative status of cells, which are also important indicators of cell antioxidant model. The establishment of cell antioxidant model should select appropriate cell lines and test indicators based on different experimental purposes and conditions. Changes of all indicators deserve to be considered for a more comprehensive evaluation of the antioxidant activity of substances. In addition, cell antioxidant model can be used to detect both the protective and repairability of antioxidants to cells, which can reflect the antioxidant activity of active substances more comprehensively. Therefore, the proposed method in the present study is generally used for screening and evaluating antioxidants. 


\section{Standards for cellular evaluating antioxidant activity}

At present, merely one available national standard is searchable to be related to antioxidant detection techniques and methods, i.e., Determination of Antioxidant Properties of Polypeptides by DPPH and ABTS Methods. Moreover, the standard has just entered the committee stage, and the method for determining antioxidant activity of polypeptide is still in vitro chemical assay described in the draft of consultation. The issuance and implementation of this standard will fill in the blank of standards for antioxidant activity evaluation of polypeptides and preliminarily address the lack of standards for antioxidant activity evaluation of cells in vitro. However, considering shortcomings of in vitro chemical assay of antioxidant activity, it is necessary to establish relevant standard for antioxidant activity evaluation of cells in vitro. After carding and discussion, in our opinion, the following issues should be emphasized and solved in developing standard for antioxidant activity evaluation of cells in vitro: (1) Determine appropriate cells for modeling in the standard. Different cells have certain differences in metabolic regulation and oxidative stress defense system, etc., which highlights the necessity to compare and explore the differences of antioxidants in different cellular environments. (2) Select suitable oxidative inducers for oxidative treatment of cells. In this process, it is necessary to compare the oxidative stress status caused by different oxidative inducers and screen appropriate oxidative inducers that accord with the pathogenesis of degenerative diseases. (3) Further clarify and unify indexes for the evaluation of antioxidant activity.

\section{Conclusion and prospects}

Antioxidants are accepted to have preventive and therapeutic effects on chronic diseases owing to its effect on scavenging free radicals, which promote the discovery of increasingly more natural antioxidants. Appropriate evaluation method of antioxidant activity is the bulwark of understanding the biological function of antioxidant. Antioxidant activity evaluation method of cells in vitro can objectively reflect the process of intracellular absorption, metabolism and distribution of antioxidants, which is more biologically relevant than chemical assay. It can better predict the antioxidant activity of substances in vivo, and can be applied to evaluate and screen antioxidant activity of common food, cosmetics, various antioxidants and dietary supplements. However, there is no proper standard for in vitro antioxidant cell modeling at present, not to mention the evaluation of the effect of the same antioxidant comparatively, which also hinders the development of antioxidant-related enterprises in China. Therefore, it is urgent to formulate relevant standards to provide technical support for the development and application of antioxidants in China.

\section{Acknowledgments}

This research was financially supported by and the Fundamental Research Funds of China National Institute of Standardization (562019Y-6673, 562014Y-3352).

Table 1. The summary of evaluation of antixidant activity in cellular method

\begin{tabular}{|c|c|c|c|c|c|}
\hline $\begin{array}{c}\text { Cell } \\
\text { lines }\end{array}$ & Passages & $\begin{array}{c}\text { Culture plates / Cell } \\
\text { density }\end{array}$ & Oxidants /Antioxidants & Assay/technique & Ref \\
\hline $\begin{array}{c}\text { HepG2 } \\
\text { cells }\end{array}$ & $12-35$ & $\begin{array}{l}\text { 96-well plates / } 6 \times 10^{4} / \\
\text { well }\end{array}$ & ABAP / extracts of fruits & $\begin{array}{l}\text { cytotoxicity (Methylene Blue assay). } \\
\text { ROS (DCHF-DA /ABAP fluorescence assay.) }\end{array}$ & [8] \\
\hline $\begin{array}{l}\text { HepG2 } \\
\text { cells }\end{array}$ & $\begin{array}{l}\text { exponential } \\
\text { growth } \\
\text { phase }\end{array}$ & $\begin{array}{l}\text { 96-well plate / } 6 \times 10^{4} / \\
\mathrm{mL} \text { with } 100 \mu \mathrm{L} / \text { well }\end{array}$ & ABAP / phenolic extracts & $\begin{array}{l}\text { Cytotoxicity ( MTT assay ) } \\
\text { CAA ( DCHF-DA fluorescence assay ), EC }{ }_{50} \\
\text { and CAA values. } \\
\text { Nitric oxide suppressive action (MTT assay) } \\
\text { expression level of iNOS and COX-2 in LPS- } \\
\text { stimulated cell } \\
\text { TNF- a, IL-1 b, IL-6 (ELISA ) } \\
\text { ERK, JNK and NF- k B (Western blotting) }\end{array}$ & [19] \\
\hline $\begin{array}{l}\text { HepG2 } \\
\text { cells }\end{array}$ & - & $\begin{array}{l}\text { 96-well plate / } 6 \times 10^{4} / \\
\text { well }\end{array}$ & $\begin{array}{l}\text { ABAP / Adinandra nitida } \\
\text { leaves extract, camellianin A } \\
\text { and B }\end{array}$ & $\begin{array}{l}\text { CAA ( DCHF-DA fluorescence assay ), EC50 } \\
\text { values. } \\
\text { Cytotoxicity test (methylene blue test) }\end{array}$ & [20] \\
\hline $\begin{array}{l}\text { HepG2 } \\
\text { cells }\end{array}$ & - & $\begin{array}{l}\text { 96-well plate / } 6 \times 10^{4} \\
\text { cells / well }\end{array}$ & $\begin{array}{l}\text { ABAP / Phytochemical } \\
\text { extraction }\end{array}$ & $\begin{array}{l}\text { Determination of Phenolics and Flavonoids. } \\
\text { ORAC, PSC and DCFH-DA / ABAP assay. } \\
\text { CAA assay. } \\
\text { Anti-proliferation Activity. } \\
\text { Cytotoxicity Assay ( Methylene blue stain ). }\end{array}$ & [21] \\
\hline $\begin{array}{c}\text { HepG2 } \\
\text { cells }\end{array}$ & - & $\begin{array}{c}\text { 96-well plate / } 6 \times 10^{4} \\
\text { cells / well }\end{array}$ & ABAP / Aloe leaves extraction & $\begin{array}{l}\text { ORAC, PSC and DCFH-DA / ABAP assay } \\
\text { CAA assay. }\end{array}$ & [22] \\
\hline $\begin{array}{c}\text { HepG2 } \\
\text { cells }\end{array}$ & - & $75 \mathrm{~cm}^{2}$ culture flasks & $\begin{array}{c}\mathrm{H}_{2} \mathrm{O}_{2}(5 \mathrm{mg} / \mathrm{L}) / \text { flavonoids } \\
\text { extracted }\end{array}$ & CMAA assay & [23] \\
\hline $\begin{array}{l}\text { HepG2 } \\
\text { cells }\end{array}$ & - & $\begin{array}{l}\text { 96-well plates } / 3 \times 10^{4} / \\
\mathrm{mL}\end{array}$ & $\mathrm{H}_{2} \mathrm{O}_{2}(400 \mu \mathrm{M}) /$ soyasaponins & $\begin{array}{l}\text { Cell viability assay ( } \\
\text { morphological analysis (observation of } \\
\text { microscope). } \\
\text { ROS (DCFH-DA fluorescence probe assay) } \\
\end{array}$ & [24] \\
\hline
\end{tabular}




\begin{tabular}{|c|c|c|c|c|c|}
\hline $\begin{array}{l}\text { HepG2 } \\
\text { cells }\end{array}$ & $10-15$ & $\begin{array}{l}\text { 96-well plate } / 6 \times 10^{4} \\
\text { cells } / \mathrm{mL}\end{array}$ & $\begin{array}{l}\text { AAPH / peptide Lys-Asp-His- } \\
\text { Cys-His (KDHCH) }\end{array}$ & $\begin{array}{l}\text { ROS levels (DCFH-DA fluorescent probe } \\
\text { assay ). } \\
\text { Cytotoxicity and cell viability assay (MTT } \\
\text { assay) } \\
\text { Antioxidant activity related enzymes (CAT, } \\
\text { SOD, GSH-PX, and GR.) } \\
\text { Apoptosis (the mitochondrial membrane } \\
\text { potential and caspase-3) } \\
\text { The level of LDH and MDA (Beyotime's } \\
\text { assay kits ) }\end{array}$ & [25] \\
\hline $\begin{array}{l}\text { HepG2 } \\
\text { cells }\end{array}$ & $10-20$ & $\begin{array}{l}\text { 96-well plate / } 6 \times 10^{4} \\
\text { cells / well }\end{array}$ & $\begin{array}{l}\text { ABAP / corn gluten peptide } \\
\text { fractions }(\mathrm{CPFs}, 0.05-2.50 \\
\mathrm{mg} / \mathrm{mL})\end{array}$ & $\begin{array}{l}\text { CAA assay (DCFH-DA fluorescent probe). } \\
\text { Cell viabilities (MTT cell proliferation assay). } \\
\text { Intracellular reactive oxygen species levels } \\
\text { Intracellular ROS level (SOD, CAT, GR } \\
\text { activity and total GSH level). }\end{array}$ & [26] \\
\hline $\begin{array}{l}\text { HepG2 } \\
\text { cells }\end{array}$ & - & - & ABAP / Phenolic compounds & $\begin{array}{l}\text { ORAC, PSC. } \\
\text { Cellular CAA assays. } \\
\text { Cytotoxicity and antiproliferative activity } \\
\text { assays. } \\
\text { Bioaccessibility of bioactive compounds. }\end{array}$ & [27] \\
\hline $\begin{array}{l}\text { HepG2 } \\
\text { cells }\end{array}$ & - & $\begin{array}{l}\text { 24-well plate } / 1.2 \times 10^{6} \\
\text { cells }\end{array}$ & t-BHP / methyl rosmarinate & $\begin{array}{l}\text { Radical scavenging ability. } \\
\text { cell viability, Cytotoxicity and cytoprotection, } \\
\text { Antioxidant activity }\end{array}$ & [28] \\
\hline $\begin{array}{l}\text { HepG2 } \\
\text { cells }\end{array}$ & - & $\begin{array}{l}\text { 96-well plates / 30,000 } \\
\text { cells per well }\end{array}$ & $\begin{array}{l}\quad 80 \mu \mathrm{M} \text { cumene } \\
\text { hydroperoxide } / 80 \mu \mathrm{M} \text { hemin / } \\
\text { anthocyanins extractions }\end{array}$ & $\begin{array}{l}\text { Lactate dehydrogenase (LDH) cytotoxicity. } \\
\text { Transient transfection and Nrf2 luciferase } \\
\text { reporter gene assay. } \\
\text { heme oxygenase1 (Hmox1), glutamate- } \\
\text { cysteine ligase, catalytic subunit (Gclc) and } \\
\text { glyceraldehyde-3-phosphate dehydrogenase } \\
\text { (Gapdh) expression level. } \\
\text { Glutathione assay. } \\
\text { Stable transfection and PON1 luciferase } \\
\text { reporter gene. } \\
\text { C11-BODIPY (581/591) lipid peroxidation }\end{array}$ & [29] \\
\hline $\begin{array}{l}\text { HepG2 } \\
\text { cells }\end{array}$ & - & $\begin{array}{l}\text { 96-well plates } / 6.0 \times \\
10^{4} \text { cells } / \text { well }\end{array}$ & $\begin{array}{l}\mathrm{ABAP} / \text { phenolic compounds } \\
\text { extraction }\end{array}$ & $\begin{array}{l}\text { PSC and CAA assays. } \\
\text { Cytotoxicity. } \\
\text { Antiproliferative Activity Assays, }\end{array}$ & [30] \\
\hline $\begin{array}{l}\text { HepG2 } \\
\text { cells }\end{array}$ & \multirow{3}{*}{ - } & $\begin{array}{l}\text { 96-well plate / } 0.1 \times 10^{6} \\
\text { cells / well }\end{array}$ & \multirow{3}{*}{$\begin{array}{l}\text { cumene hydroperoxide }(8 \\
\mathrm{mM}) / \text { hemin }(8 \mu \mathrm{M}) / \\
\text { astaxanthin }(10 \text { and } 20 \mu \mathrm{M})\end{array}$} & $\begin{array}{l}\text { DPPH, galvinoxyl and superoxide radical } \\
\text { scavenging experiments. } \\
\text { mRNA levels of Gclc and Nrf2. } \\
\text { Glutathione Assay. } \\
\text { Neutral Red Cell Viability Assay. } \\
\text { Lipid peroxidation (BODIPY assay) }\end{array}$ & \multirow{3}{*}{ [31] } \\
\hline $\begin{array}{l}\text { PON1- } \\
\text { Huh7 } \\
\text { cells }\end{array}$ & & $\begin{array}{l}\text { 24-well plate / } 0.15 \times \\
10^{6} \text { cells / well }\end{array}$ & & $\begin{array}{l}\text { Paraoxonase Activity. } \\
\text { Neutral Red Cell Viability Assay }\end{array}$ & \\
\hline $\begin{array}{l}\text { Huh7 } \\
\text { cells }\end{array}$ & & $\begin{array}{l}\text { 24-well plate / } 0.15 \times \\
10^{6} \text { cells / well }\end{array}$ & & $\begin{array}{l}\text { Nrf2 Transactivation. } \\
\text { the expression level of antioxidant activity } \\
\text { related enzymes }\end{array}$ & \\
\hline $\begin{array}{l}\text { Caco-2 } \\
\text { cells }\end{array}$ & $20-50$ & $\begin{array}{l}24 \text { or } 48 \text {-well plates / } 2 \\
\times 10^{5} \text { cells } / \mathrm{mL}\end{array}$ & $\begin{array}{l}\mathrm{H}_{2} \mathrm{O}_{2} \text { ( final concentration } 1 \\
\mathrm{mM}) / \text { phenolic extracts of } \\
\text { purple carrots or potatoes }\end{array}$ & $\begin{array}{l}\text { ORAC, FRAP and DPPH antioxidant assays. } \\
\text { Pro-inflammatory cytokines IL-1 } \beta, \text { IL-6, IL- } 8 \\
\text { and TNF- } \alpha \text { (RT-PCR) } \\
\text { intracellular CAT, SOD, GPx, GR } \\
\text { activity(colorimetric Assay Kits), }\end{array}$ & [32] \\
\hline $\begin{array}{l}\text { Caco-2 } \\
\text { cells }\end{array}$ & $4-25$ & $\begin{array}{l}\text { 96-well plate } / 1.5 \times 10^{4} \\
\text { / well }\end{array}$ & $\begin{array}{l}\text { tert-butyl hydroperoxide (t- } \\
\text { BHP) / water-soluble peptides } \\
\text { (WSPs) extract }\end{array}$ & $\begin{array}{l}\text { ABTS-radical scavenging activity } \\
\text { Cytotoxicity ( MTT assay), } \\
\text { Cellular ROS determination (DCHF-DA } \\
\text { fluorescence assay), } \mathrm{EC}_{50} \text { and CAA values. }\end{array}$ & [33] \\
\hline $\begin{array}{l}\text { Caco-2 } \\
\text { cells }\end{array}$ & $45-55$ & $\begin{array}{l}\text { 96-well plate } / 2 \times 10^{5} / \\
\text { well }\end{array}$ & $\begin{array}{l}\mathrm{AAPH} / \text { all-E-lutein and Z- } \\
\text { luteins }\end{array}$ & $\begin{array}{l}\text { FRAP, DPPH and ORAC-L assay. } \\
\text { Absorption and secretion of lutein isomers by } \\
\text { Caco-2 cells } \\
\text { CAA ( DCHF-DA fluorescence assay ). }\end{array}$ & [34] \\
\hline $\begin{array}{l}\text { Caco-2 } \\
\text { cells }\end{array}$ & 37 & $\begin{array}{c}\text { 96-well plate } / 5 \times 10^{5} / \\
\mathrm{mL}\end{array}$ & $\begin{array}{l}\text { AAPH / phenolic (Mangifera } \\
\text { indica L. bark extracts ) }\end{array}$ & $\begin{array}{l}\text { Antioxidant capacity (DPPH, ORAC and } \\
\text { ABTS* assay). } \\
\text { CAA assay (tested with a CellTiter 96® } \\
\text { Aqueous One Solution Cell Proliferation } \\
\text { Assay). } \\
\text { Intestinal permeability assay. }\end{array}$ & [35] \\
\hline $\begin{array}{l}\text { Caco-2 } \\
\text { cells }\end{array}$ & - & 96-well plate / - & $\begin{array}{c}600 \mu \mathrm{M} \text { ABAP / resveratrol, } \\
\text { resveratrol-loaded zein-BSA } \\
\text { nanoparticles, resveratrol- } \\
\text { loaded zein-BSA-CA } \\
\text { nanoparticles } \\
\end{array}$ & $\begin{array}{l}\text { DPPH radical scavenging activity. } \\
\text { Ferric reducing power. } \\
\text { ORAC and CAA assay. }\end{array}$ & [36] \\
\hline $\begin{array}{l}\text { Caco-2 } \\
\text { cells }\end{array}$ & - & $\begin{array}{l}\text { 96-well plate } / 2 \times 10^{4} \\
\text { cells / well }\end{array}$ & AAPH / polyphenol extraction & $\begin{array}{l}\text { Chemical antioxidant activity (DCHF-DA / } \\
\text { AAPH, Trolox standards ). } \\
\text { Cytotoxicity and CAA assay }\end{array}$ & [37] \\
\hline
\end{tabular}




\begin{tabular}{|c|c|c|c|c|c|}
\hline $\begin{array}{l}\text { Caco-2 } \\
\text { cells }\end{array}$ & & $\begin{array}{l}\text { 96-well plate / } 5 \times 10^{4} \\
\text { cells }(200 \mu \mathrm{L} / \text { well })\end{array}$ & $\begin{array}{l}\text { ABAP / curcumin and } \\
\text { curcumin nanoliposomes }\end{array}$ & $\begin{array}{l}\text { Cellular antioxidant activity. } \\
\text { Cellular Uptake Assays assays }\end{array}$ & [38] \\
\hline $\begin{array}{l}\text { Caco-2 } \\
\text { and } \\
\text { HT-29 } \\
\text { cells }\end{array}$ & - & $\begin{array}{l}\text { 96-well microplate / } 5 \times \\
10^{5} \text { cells } / \mathrm{mL}\end{array}$ & AAPH / phenolics extraction & $\begin{array}{l}\text { Cell viability. } \\
\text { Cellular antioxidant activity. } \\
\text { Caco-2/HT-29 monolayer permeability. }\end{array}$ & [39] \\
\hline $\begin{array}{l}\mathrm{HeLa} \\
\text { cells }\end{array}$ & log phase & $\begin{array}{l}96 \text {-well plate } / 1 \times 10^{5} / \\
\mathrm{mL} \text { with } 100 \mu \mathrm{L} / \text { well }\end{array}$ & $\begin{array}{c}\mathrm{H}_{2} \mathrm{O}_{2}(100 \mu \mathrm{l} / \text { well }(100 \mu \mathrm{M})) / \\
\text { rosemary ethanol extract, } \\
\text { rosmarinic acid and rosmanol }\end{array}$ & $\begin{array}{l}\text { HPLC-DPPH and } \\
\text { OH radical scavenging assay, } \\
\text { Cell viability assay. } \\
\text { DCHF-DA fluorescence assay. }\end{array}$ & [40] \\
\hline $\begin{array}{l}\text { HaCat } \\
\text { cells }\end{array}$ & - & $\begin{array}{l}\text { 96-well plate / } 6 \times 10^{4} \\
\text { cells / well }\end{array}$ & $\begin{array}{l}\text { AAPH }(600 \mu, \mathrm{M}) / \text { flavonoid } \\
\text { extractions }\end{array}$ & $\begin{array}{l}\text { cytotoxicity. } \\
\text { ORAC, CAA and PSC assay. }\end{array}$ & [41] \\
\hline $\begin{array}{l}\text { Red } \\
\text { blood } \\
\text { cells } \\
(\mathrm{RBCs})\end{array}$ & - & 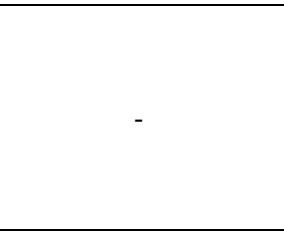 & $\begin{array}{l}\text { hypochlorite and AAPH / (+)- } \\
\text { catechin, (-)-epicatechin, (-)- } \\
\text { epigallocatechin, (-)- } \\
\text { epicatechin gallate and (-)- } \\
\text { epigallocatechin gallate, } \\
\text { Curcumin and hydrocinnamic } \\
\text { acid, Glutathione }\end{array}$ & $\begin{array}{l}\text { The cell-free assay: ABTS*, FRAP and } \\
\text { Protection against } \mathrm{NaOCl} \text { or APPH assays. } \\
\text { Erythrocytes hemolysis assays } \\
\text { ROS and } \mathrm{IC}_{50} \text { value, }\end{array}$ & [42] \\
\hline $\begin{array}{c}\text { Red } \\
\text { blood } \\
\text { cells }\end{array}$ & - & 96-well plate / - & AAPH / herbal extracts & ORAC and CAA assays. & [43] \\
\hline $\begin{array}{l}\text { Human } \\
\text { Plasma }\end{array}$ & - & - & AAPH / polyphenolic fractions & $\begin{array}{l}\text { Lipoxygenase (LOX) and hyaluronidase } \\
\text { (HYAL) inhibition tests. } \\
\text { DPPH, FRAP and TBARS assay. } \\
\text { Cellular antioxidant activity (3-Nitrotyrosine } \\
\text { and Thiols, Lipid Hydroperoxides, TBARS, } \\
\text { FRAP and Cellular Safety). }\end{array}$ & [44] \\
\hline $\begin{array}{l}\mathrm{PC} 12 \\
\text { cells }\end{array}$ & - & $\begin{array}{l}\text { 6-well plate } / 4 \times 10^{5} \\
\text { cells / well }\end{array}$ & $\mathrm{A} \beta_{1-42} /$ shikonin & $\begin{array}{l}\text { Cell Viability and LDH assay. } \\
\text { Lipid Peroxidation and ROS assays. } \\
\text { SOD, CAT and GSH-Px activities. } \\
\text { The levels of Bax, Bcl-2, and activated } \\
\text { caspase-3 protein., mitochondrial membrane } \\
\text { potential. }\end{array}$ & [45] \\
\hline $\begin{array}{l}\text { AML- } \\
12 \text { cells } \\
\text { and } \\
\text { RAW } \\
264.7\end{array}$ & - & $\begin{array}{l}\text { six-well plates } / 1.2 \times \\
10^{6} \text { cells } / \text { well }\end{array}$ & / Coffee extracts & $\begin{array}{l}\text { DPPH free radical scavenging activity. } \\
\text { ABTS radical scavenging activity. } \\
\text { cell viability, antioxidant and anti- } \\
\text { inflammatory assay. } \\
\text { intracellular glutathione concentration. } \\
\text { mRNA expression levels of GSH synthesizing } \\
\text { enzymes and anti-inflammatory factors }\end{array}$ & [46] \\
\hline $\begin{array}{l}\text { HEK- } \\
293 \\
\text { cells }\end{array}$ & $<20$ & $\begin{array}{l}\text { 96-well plates / } 5.0 \times \\
10^{4} \text { cells } \mathrm{mL}^{-1}\end{array}$ & $\begin{array}{l}\text { AAPH / pentapeptide } \\
\quad(\text { WNWAD })\end{array}$ & $\begin{array}{l}\text { cell viability ( MTS assay), ORAC value. } \\
\text { ROS (DCHF-DA /AAPH fluorescence } \\
\text { assay),. } \\
\text { anti-apoptotic protein Bcl-2 and apoptosis } \\
\text { executor proteins (Western blot) }\end{array}$ & [47] \\
\hline
\end{tabular}

Note: ORAC:oxygen radical absorbance capacity; FRAP : ferric reducing antioxidant power; MTT: 3-(4,5-dimethylthiazol-2-y1)2,5-diphenyltetrazo lium bromide; CAA : cellular antioxidant activity; DCHF-DA: 2',7'-dichlorofluorescin diacetate; ABAP: 2,2'azobis(2-amidinopropane) dihydrochloride; AAPH: 2,2'-azobis-(2-methylpropionamidine) dihydrochloride; ABTS: 2,2'-azinobis-3ethylbenzothiazoline-6sulfonic acid; CAT: Catalase ; SOD: superoxide dismutase; GPx: glutathione per-oxidase; GR: glutathione reductase; iNOS: inducible nitric oxide synthase; COX-2: cyclooxygenase-2; PSC: peroxyl radical scavenging capacity; CMAA: cellular metabolomics antioxidant activity; ROS: reactive oxygen species; TBARS: thiobarbituric acid-reactive substances.

\section{References}

1. L. Zhao, JY Su. LL, JP Chen, SQ Hu, X Zhang, TF Chen, Food Res. Int., 66,186-196( 2014).

2. T. Finkel, J. Biol. Chem., 287, 7 (2012).

3. D. Harman, Proc Natl Acad Sci USA, 88, 12 (1991).

4. L. Xu, L.R. Howard, Zh. Xu, New York: John Wiley \& Sons Inc, (2012).

5. DJ Huang, BX Ou, R.L. Prior, J. Agric. Food Chem., 53, 6 (2005).

6. MJ Shi, XY Wei, JX, BJ Chen, DY Zhao, S Cui, T Zhou, Food Chem., 215, 76-83( 2017).

7. P.B.F. Biondo, C. Fabiana, Z. Fernando, L.U.R. Chiavelli, E. Pilau, I. Prado, J.V. Visentainer, Curr. Bioa. Comp., 13, 2 (2017).
8. k. L. Wolfe, RH Liu, J Agri Food Chem., 55, 22 (2007).

9. L.F Carvalho, A.M.F Silva, A.A Carvalho, Clin. Exp. Pharmacol. Physiol., 44, 10 ( 2017).

10. R.S. Guleria, A. Jain, V. Tiwari, M.K. Misra, Mol. Cell Biochem., 236, 1-2(2002).

11. Minati Das, Pratima Sur, Aparna Gomes, J.R. Vedasiromoni, D.K. Ganguly, Phytother Res., 16: S1 (2002).

12. SS Gong, YX Li, MT Zhang, J Du, PS Ma, WX Yao, R Zhou, Y Niu, T Sun, JQ Yu, Neurochem. Res., 41, 11 (2016).

13. B. Vashistha, A. Sharma, V. Jain, Nutr. Neurosci.,20, 1(2017).

14. S.R. Finfer , J. Cohen, Resuscitation, 48, 77-90, (2001). 
15. A. Rodrí guez-Rodrí guez, J.J. Egea-Guerrero, F. Murillo-Cabezas, A. Carrillo-Vico, Curr. Med. Chem., 21, 1201-11, (2014).

16. A. Rodrí guez-Rodrí guez, J.J. Egea-Guerrero, Á. Vilches-Arenas, E. Gordillo-Escobar, Z.R de AzúaLópez, F. Murillo-Cabezas, Clin. Chem. Med., 55, 11 (2017).

17. A. Kartalis, M. Didagelos, I. Georgiadis, G. Benetos, N. Smyrnioudis, H. Marmaras, P. Voutas, C. Zotika, S. Garoufalis, G. Andrikopoulos, Eur. J. Prev. Cardiol., 23, 722-729 (2016).

18. A. Triantafyllou, N. Chaviaras, T.N. Sergentanis, E. Protopapa, J. Tsaknis, J. Ethnopharmacol., 111, 4349, (2007).

19. T.T. Zhang, T. Hu, J.G. Jiang, J.W. Zhao, W. Zhu. RSC Adv., 8 (2018).

20. BG Liu, YS Chen, HZ Mo, HJ Ma, J Zhao, J. Funct. Foods, 23, 423-431 (2016).

21. HL Wang, XB Guo, XD Hu, T Li, X Fu, RH Liu, Food Chem., 217, 773-781 (2016).

22. BG Liu, YS Chen, HZ Mo, HJ Ma, J Zhao, Int. J. Food Sci. Technol., 51, 1489-1494 (2016).

23. JT Wei, QP Hu, NL Wang, YW Liu, D Pei, DL Di, Chromatographia, 80, 4(2017).

24. LJ Zhu, MH Zhang, XY Liu, H Liu, YT He, B Wang, T Ma, Chem. Pap., 71, 3(2017).

25. R Liang, Sh Cheng, YF Dong, HP Ju, Food Res. Int., 121, 336-347(2019).

26. LY Wang, LD, ZhP Yu, T Zhang, Sh Ma, JB Liu, Food Res. Int., 90, 33-41(2016).

27. RX Guo, XX Chang, XB Guo, C.S. Brennan, T Li, X Fu, RH Liu, Food Funct., 8, 4229-4240 (2017).

28. A.G. Adomako-Bonsu, S.L.F. Chan, M. Pratten, J.R. Fry, Toxicol. In Vitro, 40, 248-255 (2017).

29. T. Esatbeyoglu, M. Rodríguez-Werner, A. Schlösser, P. Winterhalter, G. Rimbach, Food Chem., 221, 447-456 (2017).

30. Y Gao, XB Guo, Y Liu, ZQ Fang, MG Zhang, RF Zhang, LJ You, T Li, RH Liu, Sci. Rep., 8, 10482 (2018).
31. J. Dose, S. Matsugo, H. Yokokawa, Y. Koshida, S. Okazaki, U. Seidel, M. Eggersdorfer, G. Rimbach, T. Esatbeyoglu, Int. J. Mol. Sci., 17 ,1 (2016)

32. H Zhang, RH Liu, R. Tsao, J. Func. Foods , 22, 363375 ( 2016).

33. N. Huma, S. Rafiq, A. Sameen, I. Pasha, M.I Khan, Asian-Australas J. Anim. Sci., 31, 2 (2018) .

34. Ch Yang, M. Fisher, C. Kirby, RG Liu, HH Zhu, H Zhang, YH Chen, Y Sun, LF Zhang, R. Tsao, Food Chem., 249, 66-76, (2018).

35. G. Vazquez-Olivo, M. Antunes-Ricardo, J.A. Gutiérrez-Uribe, T. Osuna-Enciso, J. León-Félix, J.B. Heredia, J. Sci. Food Agric., 99, 7 (2019).

36. YT Fan, YX Liu, LY Gao, YZ Zhang, J Yi, Food Chem., 261, 283-291 (2018).

37. A. 'Alvarez, J. Poejo, A.A. Matias, C.M.M. Duarte, M.J. Cocero, R.B. Mato. Food Bioprod. Process., 106, 162-170 (2017).

38. X Chen, LQ Zou, J Niu, Molecules, 20, 1429314311(2015).

39. R. Pacheco-Ordaz, M. Antunes-Ricardo, J.A. Gutiérrez-Uribe, G.A. González-Aguilar. , Int. J. Mol. Sci. , 19, 2 (2018).

40. JY Nie, R Li, YWang, J Tan, ShH Tang, ZT Jiang. J. Food. Biochem., 43, 7 (2019).

41. C. Bende, S. Graziano, Nutrafoods, 14, 2 (2015).

42. M. Grzesik, K. Naparło, G. Bartosz, I. SadowskaBartosz, Food Chem., 241, 480-492 (2018).

43. M. Blasa, D. Angelino, L. Gennari, P. Ninfali, Food Chem., 125, 685-691 (2011).

44. A. Kicel, J. Kolodziejczyk-Czepas, A.Owczarek, M.Rutkowska, A. Wajs-Bonikowska, S. Granica, P. Nowak, M.A. Olszewska, Oxidative Medicine and Cellular Longevity, 2018, 3482521 (2018)

45. YN Tong, L Bai, R Gong, JL Chuan, XM Duan, YX Zhu, Sci. Rep., 8, 1 (2018).

46. S. Jung, M.H. Kim, J.H. Park, Y. Jeong, K.S. Ko, J. Med. Food., 20, 6 (2017).

47. JB Liu, ZF Chen, JHe, Y Zhang, T Zhang, Y Jiang, Food Funct., 5, 12 (2014). 